\title{
INCREASE REGIONAL POTENCY IN ORDER TO DEVELOP TOURISM- BASED ON RESIDENT
}

\author{
Dewi Winarni Susyanti, SE.MSi \\ Study Programme of MICE \\ Jakarta State of Polytechnic \\ Email: dwinarni@hotmail.com
}

\author{
Dr. Nining Latianingsih, SH.MH \\ Study Programme of MICE, \\ Jakarta State of Polytechnic. \\ Email : nilaahen@yahoo.co.id
}

\begin{abstract}
The rural tourism concept with a unique product characteristics, distinctive and environmental friendly seems to be a new solution for the tourism development in the world. In response for the displacement of tourist interest, in Indonesia grow new tourism options such as rural tour in various provinces in Indonesia. The Development of Rural Tourism is not only beneficial for the emergence of alternative tours to fulfill the tourist interest, but also can be used as a solution for problem poverty, cultural preservation and environmental conservation. Indonesia in general and West Java particularly is an area which have uniqueness in the village. But, both societies and destination managers have not realized its potential. So there are many villages, which doesn't well maintained. So this study focus on identification of the potential of various regions in West Java to be a rural tourism. The identification results will be used to the development model of Village Community Empowerment and Poverty Alleviation through Tourism Village. In the first year, from survey and interview, we got some datas about the conditions for rural tourism development potential of community -based tourism-, also the potential of tourism in rural locations. Besides, to complete the model of community empowerment and poverty through rural tourism, the success key is the readiness of the population to open and change. To prepare societies to be able to manage the rural tourism, the competence training should be given. So that the preservation of culture and poverty alleviation can be realized.
\end{abstract}

Keywords : rural tourism, rural tour, society, development, poverty alleviation, cultural preservation .

\section{PREFACE}

Tourism sector as one of the important sources of foreign exchange, are very able to provide significant contributions to the development. Conventional tourism products are now being left, and tourists start to choose tourism products which has special respect to the environment, nature, and culture. Tourist satisfaction no longer rely on the natural beauty and completeness of tourist facilities but also on the intensity of interaction with the environment and local communities. Based on the above facts it is necessary to formulate a form of sustainable tourism development to be more appropriate in the future. The concept of rural tourism (rural tourism) with a unique product characteristics, distinctive, and environmentally friendly, seems to be a new solution for the development of tourism in the world. In response to the shift on the interest of the travelers, Indonesia grows new tourism options in the form of tourist villages in various provinces in Indonesia.

The understanding of rural tourism is quite varied, among others say is a form of living environment which has special characteristics at both nature and culture, in accordance with the demands of travelers where they can enjoy, recognize, appreciate and learn the peculiarities of the village and all its appeal. In practice, the travelers often live in or live close to the traditional atmosphere and learn about village life and the local environment, so there is a learning process of the people (hosts) to the tourists (guests), so the guests were able to reward the local values which still be embraced by the local community.

The tourists who come to the tourist village will be able to enjoy the pristine nature of rural life and living in the village with its custom. Travelers staying with people, sleeping in a simple but clean and healthy room, and traditional food is the main course to be served. That way the tourists feel the satisfaction of the reception and care from the villagers.

Besides supported by the facts above, travelers trend is now more rational and has a character that tourist satisfaction isn't based only on modern tourism facilities, but also on the flexibility and intensity of interaction with the environment and local communities. Based on this, the development of tourist village has become a new way for the development of tourism in Indonesia. The purpose of this study is to identify and recognize the potential of a village to become a tourist village.

\section{Methodology}

Approaching method is using sociologic normative approach and empirical normative, by collecting data not only from the literature but also in the field and research field, means to communicate with the public on the basis of observations of the activities of the poor in rural tourism, the problems studied is the relationship between sociological factors, psychologically. Methods of data collection is done directly on the objects of research that has to do with the problem under study. Source of information will be extracted from reliable information, also literature research in order to obtain a theoretical foundation opinions of other authorized parties, community groups and relevant government officials. 


\section{THEORY}

Determination and application of Law No. 32 of 2004 on regional governance and Law No. 24 of 2004 on fiscal balance between the central government and local governments have brought big changes for local governments. Both laws are great benefit to local governments. The positive impact of the legislation is the independence of each region to manage all existing potentials that are expected to emerge justice. Thus the economic potential and the natural wealth that was much more absorbed into the central government can be distributed to local governments in the larger portion. In addition, local governments can implement policies in accordance with the local development potential of the area because local governments are more aware of the advantages of the region. The development of the village into a tourist village that rests to the unique culture of the village community actually shows that it is need to develop the ecosystem to protect the indigenous villages.

The above conditions requires immediate research of the model of community empowerment and poverty alleviation through the development of rural tourism. The main benefit of this research is, the re-emergence on the public confidence that they have the potential to be able to further assist local governments in reducing poverty. More of it, the success of community empowerment through the development of rural tourism can boost confidence and self Indonesian society.

\section{ANALYSIS}

The first year of the three years plan of research, is to do a literature study on rural tourism. The existence of the tourist village is now urgently needed. Making all the village into a tourist village will complicate the task of local government. Therefore it takes help from universities to assess the potential of each village to be used as a tourist village. Synergy between universities and local governments will result in activities that are objective, so that the community and the village would grow into the vision of tourism products and have a sale value, at the same time will also boost the value of local culture to the outside world. By looking at the potential of what is suitable to be developed in the village, the village is expected to become a tourist destination village. By looking at the potential of what is suitable to be developed in the village, the village is expected to become a tourist destination village.

Reports of Human Resource Development Resource Development Agency-Ministry of Culture and Tourism (2009) describes the tourism sector as one of the important source of foreign exchange. Although tourism is a significant contribution to the development, but at the same time it turns out that activities tourism industry has also spawned a number of negative effects, such as deterioration of the quality of the environment, displacement of local culture and socio-economic disparities among the people. Negative impacts of tourism on the environment not only in Indonesia but in almost all over the world. As a result, there is a trend to a shift in market orientation and preference in the selection of travel products.

Tourist village should be distinguished from village tour, where the tourist only making visit to rural areas, but they don't stay in the village. The problem of "stay in the village" is used as the difference between the tourist village to village tour. Stay in the village becomes an important thing, because to this day a long stay (length of stay) is still a benchmark for measuring the success of an attraction.

Tourists who come to the tourist village will be able to enjoy the clean nature of the countryside and feel to live in village with a number of custom. Travelers staying with people, sleeping in a simple but clean and healthy room, traditional food is the main course to be served during the tour, so the tourists feel the satisfaction of the villagers reception and cares. It is in order to increase tourism activities through community-based empowerment.

The Agency for Rural Empowerment and Governance, Badan Pemberdayaan Masyarakat dan Pemerintahan Desa (BPMPD) has established 23 Rural Tourism Development Potential Conditions and Community-based Tourism Travel and tourism potential in the location village / district that could be developed in Bogor regency. Rural tourism should be well managed and supported by the entire village. To get the support of the population, the planning of rural tourism should be regulated from the beginning so that the majority of the population can be involved in this project. Residents should be prepared to be able to be a good host. They have to be trained how to receive guests, arranging rooms, preparing the house so clean and decent inhabited by tourists, cooking properly served traditional foods, as well as to revive the culture of the village that had been almost extinct.

Therefore, the key to the success of the tourist village is the readiness of the people to open up and change. To prepare the residents to manage rural tourism, some management training should be given the tourist village. This requires training curriculum in accordance with the competencies that are expected to be possessed by the villagers.

\section{CONCLUSION}

From the results of field surveys to several tourist villages can be seen that the villagers do not have adequate knowledge and skills in managing rural tourism. Departing from this, then there is an indication that the knowledge of the management of the tourist village is a skill that is needed by the existing rural tourism or for people who want to develop their village into a tourist village. Therefore, it is necessary to develop a knowledge that can enhance the knowledge and skills in managing rural tourism. The development of a model of rural tourism is expected to be a guideline for other areas to contribute to develop the village into a tourist village. 


\section{REFERENCES}

[1] Adi, Rianto, 2004, Metodologi Penelitian Sosial dan Hukum, Jakarta: Granit.

[2] Badan perencanaan Pembangunan Nasional , 2006, Buku Potensi Ekonomi

[3] BPS Pusat, 2006, Tingkat Kemiskinan di Indonesia Tahun 20052006.Available at: http://www.bps.go.id/releases/files/kemiskinan01September 2006.pdf

[4] Combs, Philip H dan Manzzor Ahmed. 1974. Memerangi $\neg$ Kemiskinan di Pedesaan Melalui Pariwisata Non-formal. $\neg$ Jakarta: CV Rajawali.

[5] Dikti, 2006. Panduan Pelaksanaan Penelitian dan Pengabdian Kepada Masyarakat. Edisi VI.

[6] Gunawan dan Sugiyanto.2000. Kondisi Keluarga Fakir Miskin. $\neg$ Jakarta

[7] Jurnal Triwulan, No.02 tahun 2006, Pembangunan Daerah_No.02 tahun 2006

[8] Mukhtar, 2003, Strategi Pemberdayaan Berbasis Kelembagaan Lokal dalam Penanganan Kemiskinan Pedesaan: Kasus Implementasi P2KP di Desa Sukadanau
[9] Mukhtar, 2006, Orang Miskin bertambah, .Kompas. 2 September 2006.

[10] Rais, M. Amien, 1995, Kemiskinan dan Kesenjangan di Indonesia. Yogyakarta: Aditya Media.

[11] Sarman, Mukhtar dan Sajogo, 2000, Masalah Penanggulangan Kemiskinan, Refleksi dari Kawasan Timur Indonesia. Jakarta: Puspa Swara.

[12] Sumarsono, dkk, 2007, Nilai-nilai Budaya Tradisional dan Kontemporer, Pusdiklat Pegawai, Depbudpar.

[13] Sumarsono, dkk, 2007, Pelestarian dan Pengembangan Nilai Budaya, Pusdiklat Pegawai, Depbudpar.

[14] Suryana, 2003, Kewirausahaan Pedoman Praktis, Kiat dan Proses Menuju Sukses. Jakarta: Salemba Empat Timbul Haryono, 2005 : Pengembangan dan Pemanfaatan Aset Budaya Dalam Pelaksanaan Otonomi Daerah, Jakarta: Mitra Publisher.

[15] Undang-Undang Nomor 32 tahun 2004 tentang Pemerintahan Daerah,

[16] Undang-Undang Nomor 24 tahun 2004 tentang Perimbangan Keuangan antara Pemerintah Pusat dan Pemerintah Daerah 